\title{
A model of cross campus entrepreneurship and assessment
}

By: William L. Tullar and Dianne H.B. Welsh.

Welsh, D.H.B., \& Tullar, W. (2014, January). A model of cross campus entrepreneurship and assessment. Entrepreneurship Research Journal, 4(1), 95-115.

Made available courtesy of De Gryter: http://dx.doi.org/10.1515/erj-2013-0038

***(C) De Gryter. Reprinted with permission. No further reproduction is authorized without written permission from De Gryter. This version of the document is not the version of record. Figures and/or pictures may be missing from this format of the document. ***

\begin{abstract}
:
Entrepreneurship education has revolutionized all aspects of business. Entrepreneurship education has progressed from programs housed only in business schools to cross-disciplinary programs in departments across college and university campuses in the past 10 years. This blended approach that encompasses various disciplines with entrepreneurship through combined learning objectives focuses on application. However, the measurement of entrepreneurial propensity in students across the curriculum, let alone in traditional Entrepreneurship programs, is sorely needed. Learning assessment is lacking. We propose and test a measure of entrepreneurial propensity across the curriculum in a successful cross-disciplinary entrepreneurship program at a public state university. Six of the nine entrepreneurship constructs showed statistically significant gains from pre- to post-test scores. Implications for further research and application are discussed.
\end{abstract}

Keywords: cross-disciplinary entrepreneurship | assessment | entrepreneurship education

Article:

***Note: Full text of article below 


\title{
Competitive Research Article
}

\section{Dianne H. B. Welsh* and William L. Tullar}

\section{A Model of Cross Campus Entrepreneurship and Assessment}

\begin{abstract}
Entrepreneurship education has revolutionized all aspects of business. Entrepreneurship education has progressed from programs housed only in business schools to cross-disciplinary programs in departments across college and university campuses in the past 10 years. This blended approach that encompasses various disciplines with entrepreneurship through combined learning objectives focuses on application. However, the measurement of entrepreneurial propensity in students across the curriculum, let alone in traditional Entrepreneurship programs, is sorely needed. Learning assessment is lacking. We propose and test a measure of entrepreneurial propensity across the curriculum in a successful crossdisciplinary entrepreneurship program at a public state university. Six of the nine entrepreneurship constructs showed statistically significant gains from pre- to post-test scores. Implications for further research and application are discussed.
\end{abstract}

Keywords: cross-disciplinary entrepreneurship, assessment, entrepreneurship education

\footnotetext{
*Corresponding author: Dianne H. B. Welsh, Bryan School of Business and Economics, The University of North Carolina at Greensboro, Greensboro, NC 27402-1670, USA,

E-mail: dhwelsh@uncg.edu
}

William L. Tullar, Bryan School of Business and Economics, The University of North Carolina at Greensboro, Greensboro, NC 27402-1670, USA, E-mail: WLTullar@uncg.edu

\section{Introduction}

Entrepreneurship education has revolutionized all aspects of business. While the development of the field of entrepreneurship education is still being debated by scholars as to whether it is fully accepted by the academic community as a whole and if it has reached maturity (Katz 2008; Kuratko 2005), there is no question that entrepreneurial education has had a major impact on society. According to Bill Aulet in a Wall Street Journal article on September 12, 2013, the reason for this is that "the subject itself is idiosyncratic, contextual, and experiential. Unlike chemistry, math, or computer programming, there are no 
definite answers in the start-up world. By definition entrepreneurs are doing the unknown and untried, so there are no algorithms for success."

We don't really have a clear blueprint on how to effectively educate one to be an entrepreneur so colleges and universities are exploring different methods of effective entrepreneurship education. One promising avenue is experiential education. For example, at the University of North Carolina at Greensboro, there is a retail store that sells handmade items made by students, faculty, and staff. The students run this experiential learning lab by performing all the functions of a retail store, including payroll, point of sale systems, procurement, operations, and marketing. Entrepreneurship education is changing the role of the university in economic development and has spurred universities to develop new kinds of learning by aligning curricula more closely with the needs of the workforce. Students today "want a job-focused education," according to a recent article by Justin Pope of The Associated Press (2012). Traditional liberal arts colleges are struggling as a result. Liberal arts account for about a third of bachelor's degrees, but particularly small liberal arts schools are struggling financially (Pope 2012). Ferrall (2011) reported that in 1986-1987, 30 of the 225 liberal arts colleges awarded $30 \%$ or more of their degrees in "vocational subjects." By 2007-2008, this figure jumped to 118. Even the Annapolis Group made up of purist liberal arts colleges reported that "vocational degrees" jumped from $6 \%$ to 17\% (http://collegenews.org/annapolis-group).

Conversely to the push for more applied degrees, the Association of American Colleges and Universities (2011) is reporting the opposite view of liberal education by employers. The Association commissioned a study from 2006 to 2009 and surveyed 305 employers with 25 or more employees. These employers rejected the trend toward "technical training" at the college level and reaffirmed the need for more liberal education, not less (p. 23). They cited asking employees to take on more responsibilities that encompass a broader range of skills and knowledge.

These essential learning outcomes included specific topics under "knowledge of human cultures and the physical and natural world, intellectual and practical skills, personal and social responsibility, and integrative and applied learning"1 (Association of American Colleges and Universities 2011, 26).

Thus, there are a variety of forces driving more universities and colleges to offer entrepreneurship education as a bridge between liberal arts and more applied education. Entrepreneurship across the curriculum is one solution to this dilemma in providing practical applications of all disciplines by increasing the students' knowledge base in specific areas of interest and the development

1 For the complete report, go to http://www.aacu.org/leap/documents/leap_vision_summary.pdf 
of an "entrepreneurial mindset," as outlined by Leo I. Higdon, Jr. in the Winter (2005) issue of Liberal Education.

While many educators agree that reform must take place in higher education at all levels - federal, state, and local - there is much controversy as to where to start and what to focus on. ${ }^{2}$ The debate on how applied higher education should be is highly controversial. However, it is one of the few times in our history where the debate has reached the magnitude of front page coverage in newspapers, websites, and discussed in blogs by the general public. Central to this debate is the role of entrepreneurship education. In 2007, the Kauffman Foundation published, On the Road to an Entrepreneurial Economy: A Research and Policy Guide. This document asserted that the entrepreneurship "process is impossible without the highly creative and highly educated individuals who will be tomorrow's high-impact entrepreneurs. Equally important, are the innovative and skilled individuals who will work for these entrepreneurs" (p. 8). Entrepreneurial skill sets are necessary not only for starting new businesses but also for growing existing innovative firms (Acs, Parsons, and Tracy 2008).

Entrepreneurship knowledge is increasingly cited as a critical success factor for all individuals. Carl Schramm, former President and CEO of the Kauffman Foundation, in a speech at Stanford University in February of 2007, said "It could be as common for an American college student to start a business as it is to anticipate marriage or parenthood."3 Graduates must also be prepared to pursue graduate studies in Entrepreneurship, an MBA, or a specific area of education. This is predicted to further enhance scientific research, innovation, and knowledge generation as well as cultural and social thinking.

Some governors, including Rick Scott of Florida and Pat McCrory of North Carolina, are advocating having students pay more for degrees that are not as applicable or economically valuable to the state at their public institutions (Pope 2012; Stancill and Frank 2013).

Research supports the contention that formal entrepreneurship education has had an impact on student entrepreneurial propensity and intentions, although it has been debated by a number of scholars (Lautenschläger and Haase 2011; Peña et al. 2010; Pittaway and Cope 2007; Von Graevenitz, Harhoff, and Weber 2010). While academic studies have been conducted on assessing the impact of entrepreneurship educational programs on actual entrepreneurship (e.g. Cox, Mueller, and Moss 2002; Duval-Couetil, Reed-Rhoads, and Haghighi 2010; Fayolle and Kyrö 2008; Peterman and Kennedy 2003; Pittaway and Cope 2007; Pittaway and Edwards 2012; Vesper and Gartner 1997), a major

2 See Kauffman Foundation (2012).

3 Schramm (2007, 1). 
issue is the lack of tools to measure the effectiveness of entrepreneurship education. In fact, the assessment of the effectiveness of entrepreneurial education across the curriculum, let alone in traditional Entrepreneurship programs, has been lacking (Athayde 2009). Meanwhile, there has been an increase in the number of entrepreneurship courses. Then there is the bigger problem of assessing the effectiveness of cross-disciplinary entrepreneurship or cross campus entrepreneurship courses. What is the impact of cross-disciplinary entrepreneurship where entrepreneurship learning objectives are blended with other disciplines in the same course? Do these courses increase the propensity of one to become a successful entrepreneur? Do discipline-specific courses blended with entrepreneurship have an impact on a student's future success? None of these questions have a satisfactory answer at the moment.

The purpose of this study is to propose a first step toward assessing the effectiveness of entrepreneurship courses across the curriculum. We begin by describing the cross campus curriculum which is the setting for our study. Next, we explain the construction of our assessment instrument, our analysis, results, conclusion, and opportunities for further research. This article offers a backdrop for other models of cross campus entrepreneurship to be developed at colleges and universities worldwide that include methods of assessment across campus so as to provide evidence of the effectiveness of cross-disciplinary entrepreneurship courses. Cross-disciplinary entrepreneurship courses are discipline-specific courses blended with entrepreneurship. For example, Creative Space: The Meeting of Art and Entrepreneurship, ENT/ART 276.

Up to this point, there have been limited measures for evaluating the effectiveness of cross-disciplinary entrepreneurship courses and if and how they make a difference in the students' overall propensity to be a successful entrepreneur. What we are looking for is student motivation to do entrepreneurial activity within the sphere of their specialty or discipline. Entrepreneurship education builds entrepreneurial motivation. Thus, it is motive that is more important in assessment than specific knowledge to begin with. We are not saying that entrepreneurial competencies are not important, but rather that motivation must be there initially.

\section{Evaluating entrepreneurship education}

Scholars (i.e., Müller and Gappisch 2005; Roberts 1989; Stormer, Kline, and Goldenberg 1999; among others) have argued that entrepreneurship is a personality trait-a combination of personality and talent that can be cultivated and trained. In our approach to measuring student outcomes in entrepreneurship courses, we follow these arguments and employ the Task Motivation Theory 
(Miner, Smith, and Bracker 1989) as a basis for our assessment instrument. Task Motivation Theory borrows heavily from McClelland's (1961) work on the need for achievement which has been widely recognized as one of the first good predictors of entrepreneurial success. Miner and colleagues recast McClelland's (1961) concepts into Task Motivation Theory (Miner, Smith, and Bracker 1989). Task Motivation Theory (Miner, Smith, and Bracker 1989) follows a more general approach to the entrepreneurial role. While it measured achievement motivation, it also measured risk taking, feedback of results, personal innovation, and planning for the future. These five separate motives may substitute for one another in producing an overall index of task motivation (Locke and Henne 1986). The Thematic Apperception Test (TAT) was developed by Henry A. Murray and Christiana D. Morgan at the Harvard Clinic at Harvard University during the 1930s (For a history, see Morgan 2002). Although McClelland's work was based on a single construct, the need for achievement (McClelland and Winter 1969), the scoring of TAT stories for need for achievement included some risk taking, feedback, and innovation, but these factors were not measured separately. Task Motivation Theory (Miner, Smith, and Bracker 1989) is based on the notion that it is necessary to measure each of these five features of the entrepreneurial role separately.

We took an even broader approach than Miner, Smith, and Bracker (1989). First, we changed the dimensions Miner, Smith, and Bracker (1989) used. We altered the sentence stems somewhat to make the test more "student friendly." Second, rather than having open-ended sentence completion we had a normative sample of students complete the sentence stems and then we built a multiple choice format by listing the most common positive, negative, and neutral student fragments. The resulting questions offer the sentence stem and then six possible ways of completing the sentence. Two of the completions show positive affect toward the stem, two show negative affect, and two are merely statements of fact. We piloted this method and found that it produced five reasonably coherent scales.

We hypothesize that all five of the dimensions derived from Miner will be positively impacted by entrepreneurship education. Just as McClelland showed that it was possible to increase other motives (McBer 1987), we hold that it is possible to increase all of Miner, Smith, and Bracker (1989) constructs by means of education. Therefore:

Hypothesis 1. Achievement, Risk Taking, Feedback, Change, and Goal Setting will all change in a positive direction after entrepreneurship education.

In addition to the kinds of constructs Miner, Smith, and Bracker (1989) and McClelland (1961) used, we added four other dimensions which the literature suggests are important learning outcomes as well as predictive of entrepreneurial success motivation: Responsibility, Intentionality, Success Motivation, and Fate Control. 
Responsibility we define as the degree to which life's outcomes are dependent upon a person, but also the person understands and takes into account the needs of peers, subordinates, and society at large. Responsibility is especially important in predicting ethical behavior of the entrepreneur. Foley, Bennett, and Wetmore (2012) argue for the importance of responsibility in the career behavior of entrepreneurs in the area of nanoscience. Vaca Vaca, del Pilar Sepulveda Calderon, and Fracica Naranjo (2010) in a qualitative study of entrepreneurs in Bogota, Colombia, concluded that having a sense of responsibility beyond continuing their enterprises was totally lacking in the entrepreneurs they studied. They concluded that the process of creating entrepreneurs should include the teaching of responsibility. We argue that the higher the responsibility level when students leave their entrepreneurship coursework, the more likely the students are to succeed as entrepreneurs and perhaps even more important, they will also understand that their responsibility goes beyond themselves and their immediate organization. Hence:

Hypothesis 2. Responsibility will change positively as a result of entrepreneurial coursework.

Intentions we define as the degree to which one is where one has planned to be. When imagining how entrepreneurs think, one must take into account their intentionality. For instance, Krueger and Kickul (2011) observe that "intentions are central to entrepreneurial thinking and thus entrepreneurial action.” They found that cognitive style has a dramatic effect on the specification of the formal intentions model and argued that the formal intentions model need not be universal. According to their research, two entrepreneurs might arrive at the same intention but through very different processes, possibly only because they differ on cognitive style. Most importantly, they argue that intentions are critical to entrepreneurial success. Following this line of reasoning, we therefore hypothesize:

Hypothesis 3. Intentions will be positively changed by entrepreneurial coursework.

Success Motivation we define as the extent to which the idea of personal success is part of the student's thinking. Part of a student's education needs to be "future perfect" - that is thinking about the outcomes of all the hard work in school. We argue that having positive mental pictures about what life will be like as a successful entrepreneur is an important educational outcome of any entrepreneurship program. Therefore, we include in our assessment questions about the extent to which students are imagining how life would be if they start their own business and make a success of it. We argue that the ability to envision one as successful is one of the main ingredients of a successful entrepreneur. Hence: 
Hypothesis 4. Success motivation will be positively changed by entrepreneurial coursework.

Lastly, Fate Control we define as the extent to which the person sees outside forces controlling his/her life. In other studies, Locus of Control or Self Efficacy has been found predictive (Brandstätter 2011). We argue in the context of the student looking ahead to an entrepreneurial career, neither of these constructs captures fully what is needed. We used items that assess whether the student sees him/herself in charge of what happens in life or not. Successful entrepreneurs do not see themselves as victims of forces outside their control. They see themselves as captains of their own ship. We argue that entrepreneurs believe that they control their own destiny rather than outside forces. Hence:

Hypothesis 5. Fate control will be positively changed by entrepreneurial coursework.

Krueger and colleagues (Krueger 2007; Krueger and Dickson 1994; Krueger and Brazeal 1994) researched cognitive control issues extensively and concluded that individuals see opportunities where he or she feels competent (self-efficacy) and exerts personal agency. While we use the Task Motivation Theory as a basis for our Entrepreneurial Propensity assessment, we argue that our measure of student outcomes incorporates the research findings of Miner, Smith, and Bracker (1989) and subsequent research which is reflected in the constructs of Responsibility, Intentionality, Success Motivation, and Fate Control.

But motivation is not the entire story. The content of entrepreneurship coursework is also vital as well as experiential learning and practice. These are the key components of most successful entrepreneurship programs, which require an internship or other experiential opportunity (Gstraunthaler and Hendry 2011; Nab et al. 2010; Vincett and Farlow 2008). Skills training that is completed in the classroom is also integral to entrepreneurial success. While we are reporting on the motivation side of our entrepreneurial propensity assessment instrument, we are in the process of completing a skill-based assessment to go along with the motivation part of our instrument.

\section{Pilot testing at UNC-Greensboro}

\subsection{History}

There are many special features that made The University of North Carolina at Greensboro (UNCG) a desirable, unique, and appropriate place to initiate such a degree program. First, UNCG had a very successful cross campus 
Entrepreneurship program initiated in 2007 called BELL (Building Entrepreneurial Learning for Life). BELL was a campus-wide, interdisciplinary effort, coordinated by an Executive Committee comprised of the Dean of the College of Arts and Sciences, the Associate Provost for Research and Public/Private Sector Partnerships, and the Dean of the Bryan School of Business and Economics and later the Distinguished Chair in Entrepreneurship. A faculty Advisory Committee met periodically with the Executive Committee to provide input and suggest new directions. The BELL initiative generated campus-wide interest from faculty and students, providing a strong cross-disciplinary linkage across the campus for the Entrepreneurship major. This interest provided a foundation to expand the development and offering of multi-disciplinary undergraduate and graduate courses in Entrepreneurship across campus. BELL has sponsored course and program development focusing on the following: Creative Industries Entrepreneurship, Public Private Innovation \& Technology, and Social Entrepreneurship. Second, the Bryan School of Business \& Economics has excellent placement of students and good relationships with businesses. We built on this to create a unique entrepreneurial internship program that targets the industry clusters of healthcare and biotech, logistics, wholesale trade, finance and insurance, food processing, and the arts. The program furthers opportunities for our students and the business community. Our students shadow an entrepreneur and work on a specific project agreed upon by the business and the student. Third, we cited regional reports that backed up our claims for the regional need for the program to build an entrepreneurial base. The reports also indicated a need to develop a stronger entrepreneurial environment to create jobs, especially to replace traditional industry sector employment. Fourth, the existing minor in Entrepreneurship at UNCG provided some of the necessary courses for majors in the proposed degree. UNCG was well-positioned to offer this degree program without significant incremental resources. This was a major issue when it was launched during the recession of 2008.

\subsection{Program demand and development}

At The University of North Carolina at Greensboro (UNCG), an Entrepreneurship curriculum was needed to build workforce knowledge to meet the demands of an ever-changing world in the Piedmont Triad and the State of North Carolina. While once a powerhouse of Fortune 100 companies, the Piedmont Triad Region of central North Carolina now struggles to compete in the global economy. Large numbers of textile, furniture, and tobacco manufacturing jobs have left the 
region permanently as a result of shifts in preferences, technological gains, labor costs, and the world economy. We lacked an entrepreneurial skill base that is mandatory to transform our population. Twenty-first century entrepreneurship skills were not available in the region. In 2008, we reconfigured the Entrepreneurship minor to include business and non-business students. There was not one major available in Entrepreneurship at a public university until UNCG's B.S. in Entrepreneurship launched in the fall of 2009. Previously, a concentration consisting of two entrepreneurship courses combined with an existing general marketing and human resource course was available. The UNCG Entrepreneurship program is designed to respond to this need. The purpose of the Entrepreneurship program is to produce graduates that are globally ready by equipping them with Entrepreneurship motives and skills for the twenty-first century.

An innovative curriculum was built on existing faculty strengths in the business school and across the University. Students have the opportunity to choose a profile based on one of seven Entrepreneurship areas based on research by one of the authors on where careers are headed for the next 20 years: Creative Industries Entrepreneurship, Family Business, Franchising, Health Care Entrepreneurship, International Entrepreneurship, Science, Innovation, and Technology, and Social Entrepreneurship. As of fall 2013, there are 44 undergraduate and graduate courses available in 22 departments with three more being proposed for 2014, which will bring the total to 47 courses in 25 departments. Majors, minors, and graduate students have the opportunity to take elective courses in the above areas. The capstone Entrepreneurship experience also is based on the seven profiles and custom designed for the student. A B.S. in Entrepreneurship, major monor for business and non-business students, and graduate courses that are blended with Entrepreneurship and the specific discipline are available. This is what makes the courses unique. The learning objectives for each cross-listed course must have a minimum of two to three learning objectives in addition to the discipline-specific learning objectives.

The professors across campus are trained in Entrepreneurship and how to blend Entrepreneurship with their discipline. This has been fueled by the Coleman Foundation's Entrepreneurship Fellows Program ${ }^{4}$ that allows each campus to develop their own formula for creating courses across campus in Entrepreneurship that emphasize self-employment. The educational objectives for the Entrepreneurship program at UNCG are as follows: analyze how

4 For more information, go to www.colemanfoundation.org 
Entrepreneurship is applied through a cross-disciplinary approach; incorporate creative and innovative thinking into entrepreneurial behavior and action; identify and evaluate ideas to determine opportunities through feasibility analysis; develop potential opportunities for action through a business plan; evaluate the financial health of the business, including cash flow and the relationship between other limited resources, in order to prepare a financial forecast; communicate entrepreneurial findings effectively, both orally and in written form; and apply the business core and entrepreneurship knowledge and skills in a capstone experiential learning opportunity.

In addition to the program's cross-disciplinary nature, there is also a multifaceted nature of entrepreneurship, which is embedded within the curriculum. The vast majority of undergraduate programs in the United States focus on Private-Sector Entrepreneurship. Our program also focuses on Public-Sector Entrepreneurship and Social Entrepreneurship, where Social Entrepreneurship is viewed within the intersection between Private and Public Entrepreneurship. This answers the call to educate students in entrepreneurship in the non-profit, public sector as well as the for-profit sector. The degree yields a unique portfolio of knowledge. That difference has permitted our graduates to fill a void in the labor market caused by the lack of graduates with entrepreneurship knowledge.

There are two facets to the Entrepreneurship Program that provides a cross campus and community structure. The Entrepreneurship CrossDisciplinary Program that focuses on Entrepreneurship across campus, while the North Carolina Entrepreneurship Center was launched in 2009 whose purpose is outreach into the community and economic development efforts. The two offices work hand-in-hand to impact Entrepreneurship and was purposely designed by the founder to provide a solid platform for growth. The academic Entrepreneurship Program has won a number of accolades since its inception in 2009, including the Award for Exceptional Activities in Entrepreneurship across Disciplines by the Global Consortium of Entrepreneurship Centers, ${ }^{5}$ The Best Practices Award for Creative Cross-Disciplinary Entrepreneurship by Small Business Institute $C{ }^{6}{ }^{6}$ the 2012 Best Emerging Entrepreneurship Program by the U.S. Association for Small Business \& Entrepreneurship, ${ }^{7}$ and the Academy of Educational Leadership Creative and Innovative Education Award. ${ }^{8}$

5 For more information, go to www.globalentrepreneurshipconsortium.org

6 For more information, go to http://www.smallbusinessinstitute.biz

7 Please see www.usasbe.org

8 For more information, go to www.alliedacademies.org 


\section{Other cross campus programs}

The Ewing Marion Kauffman Foundation first funded interdisciplinary initiatives around the country at 19 colleges and universities in 2003, called the "Kauffman Campuses" program. ${ }^{9}$ While most of these colleges and universities still have some form of cross-disciplinary programming, most did not blossom to the full extent originally conceived by the Kauffman Foundation. For instance, many to this day have only a minor and no cross-disciplinary major available. The Coleman Foundation actually had started merging entrepreneurship with the disciplines across campus before the Kauffman Foundation, with Coleman Chairs at Saint Louis University, ITT, and others from the arts to technology classes with entrepreneurship. The Coleman Foundation moved to the next level from specific campuses to nationwide with 19 campuses and 150 Coleman Cross Campus Fellows that are new or returning in 2013. In all there has been 387 professors trained in Entrepreneurship across campus. There is no official count as to the number of cross campus programs in the United States or around the world. However, it is evident that cross-disciplinary programs continue to flourish in various forms unique to the college or university.

A recent article in BizEd (Bisoux 2012) outlined programs at the University of Dayton, New Mexico State University, and the University of Illinois. While each of these programs had a different take on cross-disciplinary education, all partnered across campus with various colleges. At the University of Dayton, the entrepreneurship program partnered with the School of Engineering to have students get first-hand exposure to business projects and to expand opportunities through the business plan competition. The two schools offer joint courses in engineering and technical innovation.

At New Mexico State University, the College of Business teams with the College of Engineering and has a four-course series on entrepreneurship as well as a fellows' ethics initiative that includes faculty from the College of Business and seven other departments. Their economic development center is supported by all deans and employs 30-35 students from every college (Bisoux 2012).

At the University of Illinois, 300 students from across campus work on 50 Illinois Business Consulting projects, which generates $\$ 250,000$ a year worth of consulting fees for the university. MBA students can now take 16 hours of nonbusiness electives. The article gives strategies for collaboration that are essential for success across campus, including "look for partners whose mission is compatible" and "identify individual(s) who are in the best positions to make the

9 Please see http://www.kauffman.org/entrepreneurship/kauffman campuses.aspx 
partnerships happen” (Bisoux 2012, 20), embrace lack of resources as a reason to "pursue these programs not to avoid them" (Bisoux 2012, 21), as well as "start with a single partnership," "test the market," "be willing to compromise," "coordinate course schedules," "help students navigate the options," "assign dedicated staff," "seek external funding, and keep communication open and on multiple levels” (Bisoux 2012, 25).

Pilegaard, Moroz, and Neergaard (2010) examined what is critical to entrepreneurial success within the humanities at Aarhus School of Business. They identified the need in the humanities to develop "twin skills" by compartmentalizing specific business, research, and institutional needs to align competing university logics to reshape processes. This aligns with the observations made at Stanford University (Nelson 2005) that identified potential misalignments between the hard and soft sciences to generate entrepreneurial opportunities. The authors identified the need for established institutional legitimacy, institutional leadership support, obtaining institutional restructuring, and the use of boundary spanning to develop the twin skills identified above (Pilegaard, Moroz, and Neergaard 2010) for success.

\section{Measuring entrepreneurial potential}

As explained above, we are elaborating on the Task Motivation Theory (Miner, Smith, and Bracker 1989) in our approach to entrepreneurial motivation. In Miner and colleagues' work, self-achievement (individual achievement) is based on one's desire to succeed through his or her own efforts and to be clearly able to attribute any success to personal causation. Risk taking is based on the desire to take moderate risks that can be handled through one's own efforts. Feedback of results is based on the desire for some clear and consistent index of the level of one's performance. Personal innovation is based on a desire to introduce novel, innovative, or unusual solutions to common problems. Planning for the future is based on the desire to think about the future and anticipate future possibilities. Measuring these five motives, Miner and colleagues examined the entrepreneurial motive extensively and have achieved considerable success in predicting entrepreneurial outcomes (Berman and Miner 1985; Smith and Miner 1983, 1985; Miner, Smith, and Bracker 1989; Miner, Smith, and Bracker, 1994). Hence, the Miner Sentence Completion Scale (MSCS), Form T has been shown to correlate significantly with annual growth in number of employees and with annual growth in sales for a sample of entrepreneurs (Miner, Smith, and Bracker 1989). In a follow-up study over 5 years after the 
original work, four of the five scales of the MSCS Form T was still significantly correlated with entrepreneurial success measures (Miner, Smith, and Bracker 1994). This study shows that it is possible to predict entrepreneurial success using projective measures. In a cross-cultural validation of the Miner Sentence Completion Scale Form T, Tullar (2001) showed that the MSCS was predictive of subsequent entrepreneurial success among Russian entrepreneurs after the fall of the Soviet Union.

As noted earlier, the MSCS Form $\mathrm{T}$ is laborious to score and includes a number of sentence stems that are foreign to students. The form has 40 sentence stems, and for each person assessed, a scorer must read the response to each of the 40 items and score the response as -1 , negatively disposed toward the stem, +1 , positively disposed toward the stem, or 0 , a mere statement of fact about the stem lacking any affect. Miner recognized this disadvantage when he reworked his Form $\mathrm{H}$ sentence completion scale so that there were six multiple choice options for each sentence stem. This eliminated the need for subjective scoring. However, Form $\mathrm{H}$ is not a measure of entrepreneurial motivation, but rather a measure of motivation to manage. Thus, it was not possible to use any of the items from Form $\mathrm{H}$ to form our measure.

We did follow Miner, Smith, and Bracker (1989) in his method of producing choices for each stem. We put together a set of 40 sentence stems that were similar to those Miner, Smith, and Bracker (1989) had shown to be valid predictors of entrepreneurial success. Our student friendly constructs are called: Change, Risk Taking, Goal Setting, Feedback, and Achievement. Our constructs are based partly on McClelland's Need for Achievement (1962) scoring system and partly on the Miner Sentence Completion Scale Form T. We made up sentence stems to fit the constructs using some of Miner's wording and some of the wording from McClelland's TAT scoring instructions. We gave these sentence stems to a sample of 80 MBA students. The students were instructed to complete the sentences with the ending that first occurred to them. Then we took the most common student completions and had a group of 12 different MBA students scale the completions on a five point scale from most positive to most negative. From the scale scores, we were able to find the two most positive statements to go with each sentence stem, the two most negative statements to go with each stem, and two statements that showed no affect at all but were merely statements of fact. In doing this, we had a 40 item multiple choice assessments which yielded scores on the five constructs mentioned above. Each construct is measured with eight different sentence stems, so a construct score could range from -8 to +8 . We attempted to get the negative and positive statements to be approximately equal in deviation from zero. 
The four constructs we added in our broadening of Task Motivation Theory, Responsibility, Intentions, Success Motivation, and Fate Control are all in the same format. They are statements such as "My parents were business owners" and the student simply answers true or false. The true/false format follows a number of personality inventories that are so constructed. The format is useful in that it is easy to answer quickly, and direct observation shows that students don't linger over the items.

The descriptive statistics for the constructs are shown in Table 1 ( $n=532)$. The Alphas are somewhat low, but we argue that we are measuring each construct with disparate sentence stems. From the sentence stems themselves, it would be hard for a person to detect what is being scored. There may be some social desirability bias in these scores as well. The fact that Feedback, Goal Setting, and Achievement should be viewed so favorably (substantially greater than 0 ) is probably due to the nature of the students who make up our sample. We argue that students who are not in entrepreneurship related courses would probably have lower means.

Table 1: Descriptive statistics entrepreneurial constructs $(n=532)$

\begin{tabular}{lrrr}
\hline Construct & Mean & Standard deviation & Cronbach's Alpha \\
\hline Change & 1.37 & 2.59 & 0.627 \\
Risk taking & -0.17 & 2.11 & 0.680 \\
Goal setting & 2.34 & 2.21 & 0.560 \\
Feedback & 3.60 & 2.44 & 0.589 \\
Achievement & 2.36 & 2.47 & 0.652 \\
Responsibility & 4.21 & 1.90 & 0.582 \\
Success motivation & 3.50 & 1.26 & 0.490 \\
Intention & 2.75 & 1.33 & 0.602 \\
Fate control & 3.76 & 1.27 & 0.731 \\
\hline
\end{tabular}

There has been a great deal of scholarship in the area of entrepreneurship since Miner's MSCS form T was created. Much of it reflects the earlier knowledge of McClelland and Winter (1969), but there are also a number of new ideas suggested. In order to avoid content deficiency, we produced four constructs based on direct structured questions: Responsibility, Success Motivation, Intentions, and Fate Control. Responsibility is measured by items such as, "Sometimes I feel that I'm not acting responsibly for myself." Success Motivation is measured by items such as, "I take steps toward realizing my dream in my spare time." Intentions is measured by items such as, "I never intended to be in the situation I am in.” Fate Control is measured by items such as, "I pay close attention to my 
daily horoscope." This construct is one we would expect to have a substantial social desirability bias since it is concerned with fortune tellers, horoscopes, and astrology. Most students are sophisticated enough to know that even if they participate in these activities, they probably shouldn't admit to it.

The items in this part of the assessment are very much like many personality assessment techniques (e.g., Personality Research Form (PRF), Helmes and Jackson 1977) in that they give a descriptive statement and respondents indicate whether this statement is true of them or not true of them. We felt that some aspects of the entrepreneurial role could be assessed by directly asking questions about the respondent's background and attitudes toward responsibility, success, etc. It is interesting to note that although the four constructs measured with direct, structured questions have larger means than the five projective constructs; their standard deviations are substantially smaller. This is because the scales of the five projective constructs are 16 point scales, whereas the four direct structured scales are smaller ranging from Intentions at eight items to Fate Control with five.

\section{Results and discussion}

Table 2 shows the intercorrelations among the constructs. Given the relatively large size of the sample of 532, most of the intercorrelations in the matrix are significant. However, the largest correlation in the matrix is only 0.35. Clearly, these constructs are assessing separate aspects of the entrepreneurial role. As was argued in Task Motivation Theory (Miner, Smith, and Bracker 1989) discussion above, the more measures of fit with the entrepreneurial role, the better is the possibility of assessing student fitness for becoming an entrepreneur and the better the assessment of the effect of coursework designed to prepare students for the entrepreneurial role.

Table 2: Intercorrelations of constructs $(n=532)$

\begin{tabular}{|c|c|c|c|c|c|c|c|c|}
\hline & Risk & $\begin{array}{r}\text { Goal } \\
\text { setting }\end{array}$ & Feedback & Achievement & Responsibility & $\begin{array}{r}\text { Success } \\
\text { motivation }\end{array}$ & Intentions & $\begin{array}{r}\text { Fate } \\
\text { control }\end{array}$ \\
\hline Change & 0.12 & 0.15 & 0.25 & 0.31 & 0.10 & 0.32 & 0.09 & 0.25 \\
\hline Risk & & 0.05 & -0.03 & 0.07 & 0.14 & 0.07 & 0.05 & 0.03 \\
\hline Goals & & & 0.26 & 0.30 & 0.25 & 0.31 & 0.23 & 0.16 \\
\hline Achievement & & & & & 0.15 & 0.34 & 0.19 & 0.17 \\
\hline Responsibility & & & & & & 0.32 & 0.35 & 0.33 \\
\hline Success & & & & & & & 0.34 & 0.35 \\
\hline Intentions & & & & & & & & 0.29 \\
\hline
\end{tabular}

Notes: All r's above 0.10 significant $p<0.05$; All r's above 0.14 significant $p<0.01$. 
Table 3: $t$-tests for pre- and post-test measures

\begin{tabular}{lrrc}
\hline Construct & Mean pre- $\boldsymbol{n}=\mathbf{5 3 2}$ & Mean post- $\boldsymbol{n}=\mathbf{9 3}$ & $\boldsymbol{t}$ statistic \\
\hline Change & 1.37 & 1.72 & 1.20 \\
Risk taking & -0.17 & 2.47 & $11.14^{\star \star}$ \\
Goal setting & 2.34 & 3.04 & $2.80^{\star \star}$ \\
Feedback & 3.60 & 3.66 & 0.22 \\
Achievement & 2.36 & 2.92 & $2.01^{\star}$ \\
Responsibility & 4.29 & 5.53 & $4.82^{\star \star}$ \\
Success motivation & 3.57 & 5.90 & $15.02^{\star \star}$ \\
Intentions & 2.78 & 3.40 & $4.49^{\star \star}$ \\
Fate control & 3.78 & 3.91 & 0.98 \\
\hline
\end{tabular}

Notes: ${ }^{\star} p<0.05 ;{ }^{\star \star} p<0.01$.

Table 3 shows the comparison of scores on the constructs before and after students' participation in entrepreneurship courses. Some may object to the large sample size. However, given the number of potential confounds in the data, it was necessary to compare a large group taking the pre-test and a somewhat smaller group taking the post-test, that is as they were completing their entrepreneurship courses. Six of the nine constructs show significant gains from pre- to post-scores.

All means comparisons differ in the right direction. However, differences from Change and Feedback are very small and not significant. It is encouraging that the students finishing entrepreneurship coursework should, in general, be higher in goal setting and achievement and lesser disposed to take long shot risks (positive scores $=$ more risk averse).

One objection to these results is that they are based on a very large sample so one would expect to get significant differences just because of the large sample. We argue that because of the heterogeneity of the sample and the variety of course work that these students complete, ${ }^{10}$ one would expect large variance compared to the mean. This is true in the case of the five projective constructs, but less true of the direct, structured constructs. As may be seen in Table 1, the standard deviations of the projective constructs are greater than two in a (potentially) 16 point scale. The standard deviations of the direct, structured constructs are all but one less than 1.5. This is likely a product of the smaller number of items in each of these scales.

A second objection to these results is that they represent a simple pre-post approach, and as such they are a pre-experimental design. We stipulate to this

10 There are 14 different entrepreneurship courses represented in this sample. 
objection. As of this writing, we haven't been able to assess a control group. The results would be more convincing if they were compared to a control group that was simply taking college courses without any entrepreneurship component. However, this is the best evidence we have at the current time.

Two of the first five constructs show very strong differences: Risk Taking and Success Motivation. We argue that this is a very strong feature of the entrepreneurship education: students learn of the high failure rate of new businesses and the personal consequences of those failures. In addition, they learn the success vocabulary and their interests are stimulated. One of the most important findings is that Goal Setting motivation has increased as a result of entrepreneurship coursework. This result by itself would make the education worthwhile.

Given the extensive literature on goal setting and its relationship to personal productivity, making students more inclined to be goal setters is a very positive outcome.

Achievement Motivation shows a modest increase, and this speaks very well of the education, since McClelland's (1961) Achieving Society it has been clear that Need for Achievement is related to entrepreneurial success. Change and Feedback do not show significant gains. This is an area for further research. Perhaps, these two aspects of entrepreneurial motivation are more genetic and less readily alterable by means of education. Hypothesis 1 is then partially supported. Three of the first five constructs show gains from pre- to postprogram.

Three of the four constructs that we added in broadening Miner's Task Motivation show significant gains. Responsibility shows a substantial gain. Students who gain in responsibility see their behavior as affecting their own and others outcomes positively. Thus, Hypothesis 2 is supported.

Success Motivation shows the biggest effect of all. During the course of their entrepreneurship studies students learn to think about what success is like and to regard the outcomes and possibilities of a successful business very positively. Hypothesis 3 is strongly supported by the results. Entrepreneurship education has a strong effect on student success imagery.

Hypothesis 4 was also supported. Intentions showed a substantial gain. That is, students learn that we have a map of the future, and we are in control when we make the things that we intend to happen actually happen. This may well be a result of business plan training in many of the courses.

Hypothesis 5 was not supported. Fate control showed virtually no effect at all. As noted above, this may well be due to social desirability: students taking college coursework are unlikely to admit freely that they follow their horoscopes or that they visit fortune tellers or psychics since they know that their teachers 
frown on such things. They show no strong inclination to report these things before or after entrepreneurship education.

\section{Conclusion}

More than cognitive declarative knowledge, students who are going to become successful entrepreneurs must be goal setters, high in Need for Achievement, and moderate risk takers. They must be responsible and intentional with a map of the future that includes success and its results. We argue that the only appropriate measure for program success cannot be cognitive declarative knowledge. Entrepreneurship taught across various curricula must have a lot of different specific knowledge in the course materials. But the common thread must be that students are attitudinally and motivationally prepared to survive in the entrepreneur's role, and as we have argued earlier, success in that role is less dependent on cognitive knowledge and more dependent on motivation and attitude. It is incumbent upon educational programs teaching entrepreneurship to instill that right set of motives and attitudes rather than simply to focus on cognitive declarative knowledge.

The sample in this study includes 14 different entrepreneurship courses taught by 14 different faculty members. That we should see a difference of this size is rather remarkable. The skills and knowledge offered in these courses are certainly useful if not indispensable to the students who take them, but it is even more encouraging that the students are acquiring motives and attitudes that will suit them well in their quest to become independent business owners.

What are clearly missing from these data are entrepreneurial outcomes. We have measured student learning, but the transfer of this learning to the world of small business is the most important part of our task. More than 50 years of research in entrepreneurship have yielded insights into what makes entrepreneurs succeed. Much of that research has been distilled into the coursework that our students take. But we need to demonstrate that our attitudinal and motivational measures of students in the classroom setting actually predict the real world outcomes of students once they leave us and begin their own entrepreneurial careers. Immediate measures of entrepreneurial success may not be very useful. It is well established that entrepreneurs fail in business several times before they succeed. The real measure is how our students are faring after 10 years and beyond.

Future research will focus on gathering real world success data on the students coming out of our program. If we can show that our educational efforts 
enhance the success rate of our students, we will have created a real benefit for our community: we will have produced a cadre of students who can contribute to the economic growth of our region as well as creating reliable predictors which can forecast who should go into entrepreneurial pursuits and who should pursue other avenues for success. Additionally, future research should be expanded on students at other universities, including those with interdisciplinary and cross-disciplinary programs. Studies should also be conducted in other countries around the globe to see if the results mirror our pilot study here on our campus in the United States.

\section{References}

Acs, Z. J., W. Parsons, and S. Tracy. 2008. High-Impact Firms: Gazelles Revisited. Washington, DC: SBA.

Association of American Colleges and Universities. 2011. The LEAP Vision for Learning. Washington, DC: Author.

Athayde, R. 2009. "Measuring Enterprise Potential in Young People." Entrepreneurship Theory \& Practice 33:481-500.

Berman, F. E., and J. B. Miner. 1985. "Motivation to Manage at the Top Executive Level: A Test of the Hierarchic Role-Motivation Theory." Personnel Psychology 38:377-91.

Bisoux, T. 2012. "Collaborative Efforts." BizEd 2:18-25.

Brandstätter, H. 2011. "Personality Aspects of Entrepreneurship: A Look at Five Meta-Analyses." Personality \& Individual Differences 51:222-30.

Cox, L. W., S. L. Mueller, and S. E. Moss. 2002. "The Impact of Entrepreneurship Education on Entrepreneurial Self-Efficacy." International Journal of Entrepreneurship Education 1:229-45.

Duval-Couetil, N., T. Reed-Rhoads, and S. Haghighi. 2010. "Investigating the Impact of Entrepreneurship Education on Engineering Students.” Peer-reviewed paper presented at NCIIA.

Fayolle, A., and P. Kyrö, eds. 2008. The Dynamics between Entrepreneurship, Environment and Education. Cheltenham: Edward Elgar Publishing. http://books.google.co.uk/books? $\mathrm{id}=$ G5Yg_V6tjwIC\& dq=“The + Dynamics + between + Entrepreneurship, + Environment + and + Education"\&hl=es\&source=gbs_navlinks_s

Ferrall, V. 2011. Liberal Arts on the Brink. Boston, MA: Harvard University Press.

Foley, R. W., I. Bennett, and J. M. Wetmore. 2012. "Practitioners' Views on Responsibility: Applying Nanoethics." NanoEthics 6:231-41.

Gstraunthaler, T., and S. Hendry. 2011. "Entrepreneurial and Accounting Education Through Action-Based Learning: The Genesis Project." Journal of Entrepreneurship Education 14:125-46.

Helmes, E., and D. N. Jackson. 1977. "The Item Factor Structure of the Personality Research Form.” Applied Psychological Measurement 1:185-94.

Higdon, L. J. 2005. "Liberal Education and the Entrepreneurial Mindset." Liberal Education 91:2-5. 
Katz, J. A. 2008. "Fully Mature but Not Fully Legitimate: A Different Perspective on the State of Entrepreneurship Education." Journal of Small Business Management 46:550-66.

The Ewing Marion Kauffman Foundation. 2007. On the Road to an Entrepreneurial Economy: A Research and Policy Guide. Kansas City: Author.

The Ewing Marion Kauffman Foundation. 2012. College 2.0: An Entrepreneurial Approach to Reforming Higher Education. Kansas City: Author. http://www.kauffman.org/uploadedFiles/ StanfordEshipWeek 032807.pdf

Krueger, N. F. 2007. "What Lies Beneath? The Experiential Essence of Entrepreneurial Thinking." Entrepreneurship Theory \& Practice 31:123-38.

Krueger, N. F., and D. V. Brazeal. 1994. "Entrepreneurial Potential and Potential Entrepreneurs." Entrepreneurship Theory \& Practice 18:91-104.

Krueger, N. F., and P. Dickson. 1994. "How Believing in Ourselves Influences Risk Taking: SelfEfficacy and Opportunity Recognition.” Decision Sciences 25:385-400.

Krueger, N. F., and J. Kickul. 2011. "So you thought the Intentions Model Was Simple? Cognitive Style and the Specification of Entrepreneurial Intentions Models." NeuroPsychoEconomics Conference Proceedings, 22.

Kuratko, D. F. 2005. "The Emergence of Entrepreneurship Education: Development, Trends and Challenges." Entrepreneurship Theory \& Practice 29:577-98.

Lautenschläger, A., and H. Hasse. 2011. "The 'Teachability Dilemma' of Entrepreneurship.” International Entrepreneurship and Management Journal 7:145-62.

Locke, E. A., and D. Henne. 1986. "Work Motivation Theories." In International Review of Industrial and Organizational Psychology, edited by C. L. Cooper and I. T. Robertson, vol. 1, 1-35. New York: Wiley.

McBer. 1987. A History of the U.S. Navy Leadership and Management Education and Training Program. Boston, MA: McBer \& Co.

McClelland, D. C. 1961. The Achieving Society. Princeton, NJ: Van Nostrand.

McClelland, D. C. 1962. "Business Drive and National Achievement." Harvard Business Review 42:103-05.

McClelland, D. C., and D. G. Winter. 1969. Motivating Economic Achievement. New York: Free Press.

Miner, J. B., N. R. Smith, and J. S. Bracker. 1989. "Role of Entrepreneurial Task Motivation in the Growth of Technologically Innovative Firms." Journal of Applied Psychology 74:554-60.

Miner, J. B., N. R. Smith, and J. S. Bracker. 1994. "Role of Entrepreneurial Task Motivation in the Growth of Technologically Innovative Firms Interpretations from Follow-up Data." Journal of Applied Psychology 79:627-30.

Morgan, W. G. 2002. “Origin and History of the Earliest Thematic Apperception Test." Journal of Personality Assessment 79:422-45.

Muller, G. F., and C. Gappisch. 2005. "Personality Types of Entrepreneurs.” Psychological Reports 96:737-46.

Nab, J., A. Pilot, S. Brinkkemper, and H. T. Berge. 2010. “Authentic Competence-Based Learning in University Education in Entrepreneurship." International Journal of Entrepreneurship and Small Business 9:20-35.

Nelson, A. J. 2005. "Cacophony or Harmony? Multivocal Logics of Technology Licensing by the Stanford University Department of Music." Industrial and Corporate Change 14:93-118. 
Peña, V., M. Transue, A. Riggieri, S. Shipp, and R. Van Atta. 2010. A Survey of Entrepreneurship Education Initiatives. Institute for Defense Analyses. https://www.ida.org/upload/stpi/ pdfs/d-4091nsfinal072910.pdf

Peterman, N. E., and J. Kennedy. 2003. "Enterprise Education: Influencing Students' Perceptions of Entrepreneurship." Entrepreneurship Theory and Practice 28:129-44.

Pilegaard, M. P., P. Moroz, and H. Neergaard. 2010. "An Auto-Ethnographic Perspective on Academic Entrepreneurship: Implications for Research in the Social Sciences and Humanities." Academy of Management Perspectives 24:46-61.

Pittaway, L., and J. Cope. 2007. "Entrepreneurship Education: A Systematic Review of the Evidence." International Small Business Journal 25:479-510.

Pittaway, L., and C. Edwards. 2012. "Assessment: Examining Practice in Entrepreneurship Education." Education + Training 54:778-800.

Pope, J. 2012. "Liberal Arts Colleges Forced to Evolve with the Market." Diverse Issues in Higher Education. Accessed February 24, 2013. http://diverseeducation.com/article/50363/\#

Roberts, E. B. 1989. “The Personality and Motivations of Technological Entrepreneurs." Journal of Engineering and Technology Management 6:5-23.

Schramm, C. 2007. "Your Place in the Entrepreneurial Economy." A Speech to the Students of Stanford University upon the Inauguration of Entrepreneurship Week USA, p. 1. http://www.kauffman.org/uploadedFiles/StanfordEshipWeek032807.pdf

Smith, N. R., and J. B. Miner. 1983. "Type of Entrepreneur, Type of Firm, and Managerial Motivation: Implications for Organization Life Cycle Theory.” Strategic Management Journal 4:325-40.

Smith, N. R., and J. B. Miner. 1985. "Motivational Considerations in the Success of Technologically Innovative Entrepreneurs: Extended Sample Findings." In Frontiers of Entrepreneurship Research, edited by J. A. Hornaday, F. Tarpley, J. A. Timmons, and K. H. Vesper. Wellesley: Babson College.

Stancill, J., and J. Frank. 2013. "McCrory’s Call to Alter Higher Education Gets Angry Response." Newsobserver.com, January 29. Accessed February 20, 2013. http://www.newsobserver. com/2013/01/29/2641893/mccrorys-call-to-revamp-higher.html

Stormer, F., T. Kline, and S. Goldenberg. 1999. "Measuring Entrepreneurship with the General Enterprising Tendency (GET) Test: Criterion-Related Validity and Reliability." Human Systems Management 18:47-52.

Tullar, W. L. 2001. "Russian Entrepreneurial Motive Patterns: A Validation of the Miner Sentence Completion Scale in Russia." International Journal of Applied Psychology 21:30-6.

Vaca Vaca, P., M. del Pilar Sepulveda Calderon, and G. Fracica Naranjo. 2010. "Bogotano Entrepreneur's Action: Beliefs and Practices.” Revista Científica Pensamiento Y Gestión 28:1-24.

Vesper, K. H., and W. B. Gartner. 1997. "Measuring Progress in Entrepreneurship Education." Journal of Business Venturing 12:403-21.

Vincett, P. S., and S. Farlow. 2008. "Start-a-Business: An Experiment in Education Through Entrepreneurship." Journal of Small Business and Enterprise Development 15:274-88.

Von Graevenitz, G., D. Harhoff, and R. Weber. 2010. "The Effects of Entrepreneurship Education.” Journal of Economic Behavior \& Organization 76:90-112. 

Copyright of Entrepreneurship Research Journal is the property of De Gruyter and its content may not be copied or emailed to multiple sites or posted to a listserv without the copyright

holder's express written permission. However, users may print, download, or email articles for individual use. 